\title{
Arsenic Accumulation in Clarias gariepinus and Effects on Catalase Activity
}

\section{Ujah II* and Chikezie NJ}

Department of Applied Biochemistry, Enugu State University of Science and Technology, Enugu, Nigeria

*Corresponding Author: Ujah II, Department of Applied Biochemistry, Enugu State University of Science and Technology, Enugu, Nigeria.

Received: August 20, 2019; Published: September 26, 2019

DOI: 10.31080/ASMI.2019.02.0385

\begin{abstract}
Heavy metals are common environmental contaminants probably due to increase in discharge of pesticides, sewage and untreated industrial effluents. One of such heavy metals is arsenic which is found in seawater, warm springs, groundwater, rivers, and lakes. In aquatic environments, arsenic occurs as a mixture of arsenate and arsenate, with arsenate usually predominating. The unrestricted application of arsenic pesticides, industrial activities, and mining operations has led to global occurrence of soluble arsenic above permissible level of $0.01 \mathrm{mg} / \mathrm{L}$. Continuous exposure of freshwater organisms including fish to low concentrations of arsenic results in bioaccumulation. The present study was designed to investigate the effect of arsenic accumulation on the catalase activity in the muscle tissues of African catfish Clarias gariepinus fingerlings. The fishes were exposed to $1 \mathrm{mgL}^{-1}, 2 \mathrm{mgL}^{-1}, 3 \mathrm{mgL}^{-1} \mathrm{and}^{4} \mathrm{mgL}^{-1}$ of sub - lethal doses of arsenic $\left(\mathrm{As}_{2} \mathrm{O}_{3}\right)$. Two fishes were randomly selected and sampled after seven days of exposure and the muscle (flesh) extracted for determination of arsenic accumulation and assay of catalase activity. The result of the catalase activity was $86.9 \mathrm{u}$ mol/ $\mathrm{min}, 13.3 \mathrm{u} \mathrm{mol} / \mathrm{min}, 14.2 \mathrm{u} \mathrm{mol} / \mathrm{min}$ and $15.1 \mathrm{u} \mathrm{mol} / \mathrm{min}$ for 1, 2, 3, $4 \mathrm{mgL}-1$ respectively in all the fishes sampled. This indicates a concentration dependent significant increase $(\mathrm{p}<0.05)$ in the values of catalase activity in all the fishes sampled when compared to the control. The results suggest that in the muscle tissue of Clarias gariepinus arsenic accumulation is quantity dependent, and that activity except for the sample exposed to $1 \mathrm{mg} / \mathrm{L}$ which recorded the highest value in catalase activity $86.9 \mathrm{u} \mathrm{mol} / \mathrm{min}$ is accumulation/concentration dependent. Thus even at sub-lethal concentration arsenic can induce oxidative stress resulting in alterations in catalase activity in the muscle of the fishes.
\end{abstract}

Keywords: Arsenic; Heavy Metals; Catalase; Catfish; Oxidative Stress; Reactive Oxygen Species (ROS)

\section{Introduction}

Metabolic activity of animals is one of the most important factors that play a significant role in heavy metal accumulation (Jorgenson., et al. 2010). Recently, the rise of advance technology has brought people to the exploration and discovery of many other purposes of heavy metals, not only for civilization, but also for their own benefits (Zaki., et al. 2015). In the industrialized world that we live in today, heavy metals are significant environmental pollutants and their toxicity is a problem of increasing significance for ecological, evolutionary, nutritional and environmental reasons (Nagajyoti., et al., 2010; Jaishankar., et al. 2013). This is due to the outstanding physiological and chemical properties of heavy metals, which has widened their range of usage in industrial processes; in fertilizer and biocides production. Contamination of aquatic system by heavy metals has for long been a source of concern, since metals accumulate in aquatic organisms such as fish and transform into persistent metallic compounds (Taweel., et al. 2011; Sercikova., et al. 2013). The accumulated toxic metal components can have adverse effects on aquatic life, which further disrupt the biological food web and eventually threaten mankind as the ultimately consumer (Mashifane and Moyo, 2014; Yuswir., et al. 2015). Aquatic ecosystem is the natural habitat of fish and water pollution directly affects the underwater fish, and human beings are indirectly at high risk by consuming these fishes (Mendil., et al. 2010; Monferran., et al. 2016). The study of bio - accumulation of heavy metal in the living tissues of aquatic animals is a significant method to monitor the pollution level of water bodies and at the same time can prove to be a helpful method in studying the biological role of heavy metals present at an increased level in fish and other aquatic organisms [1].

\section{Materials and Methods}

Fish samples used were procured from the Applied Biology and Biotechnology, Enugu State University of Science and Technology (ESUT) fish farm on $26^{\text {th }}$ June, 2018. Deionized water was procured from the University of Nigeria Teaching Hospital Enugu (UNTH), on $26^{\text {th }}$ June, 2018. The collected fish samples were allowed to acclimatize under laboratory conditions for seven (7) days prior to 
experimentations. The fingerlings were subjected to graded doses of the heavy metals to determine safe doses for exposure. After determining the safe dose, the fingerlings were exposed to sub-lethal concentrations ranging from $1-4 \mathrm{mgkg}^{-1}$. Two fish samples were collected from each concentration for heavy metal determination at and catalase assay at the end of seven (7) day period.

\section{Statistical analysis}

Data obtained in this study were analyzed as Mean \pm Standard Deviation $(\mathrm{M} \pm \mathrm{SD})$. The data obtained were analyzed using one way analysis of variance (ANOVA) using statistical package and service solution (SPSS) and where significant $(\mathrm{P}<0.05)$ difference were obtained, Scheme multiple comparison were used to detect the source of difference.

\section{Results}

\begin{tabular}{|l|c|}
\hline $\begin{array}{c}\text { Concentration } \\
\text { Introduced (mg/kg) }\end{array}$ & $\begin{array}{c}\text { Accumulation } \\
\text { (mg/kg) M } \mathbf{S D}\end{array}$ \\
\hline 1 & $0.000 \pm 0.000$ \\
2 & $0.018 \pm 0.002$ \\
3 & $0.021 \pm 0.001$ \\
4 & $0.031 \pm 0.000$ \\
Control & $0.000 \pm 0.000$ \\
\hline
\end{tabular}

Table 1: Concentration of arsenic accumulated in the muscle after 7 days of exposure.

* The result is significant at $\mathrm{p}<0.05$.

\begin{tabular}{|l|c|}
\hline Concentration $(\mathbf{m g} / \mathbf{k g})$ & Catalase Activity $(\boldsymbol{\mu m o l} / \mathbf{m i n})$ \\
\hline 1 & 86.900 \\
2 & 13.300 \\
3 & 14.200 \\
4 & 15.100 \\
\hline
\end{tabular}

Table 2: Concentration of arsenic introduced and the corresponding catalase activity.

\begin{tabular}{|l|c|}
\hline \multicolumn{1}{|c|}{ Accumulation(mg/kg) } & Activity $(\boldsymbol{\mu m o l} / \mathbf{m i n})$ \\
\hline $0.000 \pm 0.000$ & 86.900 \\
\hline $0.018 \pm 0.002$ & 13.300 \\
\hline $0.021 \pm 0.001$ & 14.200 \\
\hline $0.031 \pm 0.000$ & 15.100 \\
\hline $0.000 \pm 0.000$ & 0.000 \\
\hline
\end{tabular}

Table 3: Accumulation of arsenic in the fish tissues and the corresponding catalase activity.

* Result significant at $\mathrm{p}<0.05$.

\section{Discussion}

This research work was done to determine the effect of arsenic accumulation on the catalase activity in the muscle tissues of Clarias gariepinus and the results are as indicated in Tables 1-3. Fish liver, kidney and muscle tissues are highly endowed with antioxidant enzymes including catalase (CAT), glutathione peroxidase (GPX), superoxide dismutase (SOD), glutathione S - transferase (GST) and glutathione reductase (GR) to protect them from oxidative stress. Variation in Clarias gariepinus muscle catalase (CAT) activity was recorded in this study. After seven (7) days of experimentation, it was observed that the control and $1 \mathrm{mgkg}^{-1}$ arsenic exposed fishes had undetected level of arsenic. However the concentration accumulated by the other fishes was in respect to quantity introduced, as the fishes exposed to $2 \mathrm{mgkg}^{-1}, 3 \mathrm{mgkg}^{-1}$, and $4 \mathrm{mgkg}^{-1}$ of arsenic all accumulated significant amount of arsenic 0.018, 0.021, $0.031 \mathrm{mg} / \mathrm{kg}$ respectively. But the catalase activity did not follow this trend. As higher catalase (CAT) activity $86.9 \mu \mathrm{mol} / \mathrm{min}$ was recorded in the fishes exposed to $1 \mathrm{mgkg}^{-1}$ arsenic, while the rest of the fishes exposed to 2,3 , and $4 \mathrm{mg} / \mathrm{kg}$ all record a gradual increase in catalase activity, compared to control fish group which showed no accumulation and consequently no activity was recorded. The elevated catalase (CAT) activity in $1 \mathrm{mgkg}^{-1}$ arsenic exposed fishes could be due to increase in production of reactive oxygen species (ROS) which consequently led to increased catalase activity in an attempt to eliminate or cushion this effect. This is in agreement with the findings made by Avci., et al. [2] in muscle and hepatic tissues of Silurus glanis, Atli and Canlis [3] in gills, liver and muscle tissues of Oreochromis niloticus. The lack of activity in control fish sample could be attributed to fact that in all the organs of fish the muscle has the lowest accumulation and activity when tests are conducted, as is emphatically published in the research by Tyokumbur., et al. [4]. The research by Nwani., et al. (2014) on Clarias gariepinus further suggests the same. There was a sharp decrease in muscle catalase (CAT) activity $13.3 \mu \mathrm{mol} / \mathrm{min}$ in fishes treated with $2 \mathrm{mgkg}^{-1}$ of arsenic. This sharp decrease in activity might be associated with the direct binding of $\mathrm{A}_{2} \mathrm{O}_{3}$ to the catalase (CAT) thiol (-SH) group as quantity was increased, which rendered active catalase (CAT) less active. This is similar to the findings by Palace., et al. (1992) who exposed rainbow trout to cadmium and reported lower CAT activity in the hepatic tissues and concluded that reduction in catalase (CAT) level is due to direct binding of metals that alter its structure. There was a gradual increase in activity $14.2 \mu \mathrm{mol} / \mathrm{min}$ and $15.1 \mu \mathrm{mol} / \mathrm{min}$ in fishes treated with $3 \mathrm{mg} / \mathrm{kg}$ and $4 \mathrm{mgkg}^{-1}$ arsenic respectively. This increase in activity from $13.3 \mu \mathrm{mol} / \mathrm{min}, 14.2$ $\mu \mathrm{mol} / \mathrm{min}$ and $15.1 \mu \mathrm{mol} / \mathrm{min}$ can be attributed to gradual adaptability to the toxicity posed by arsenic as oxidative stress abounded. This is in agreement with the findings made by Firat and Kargin [5], suggesting that as a result of oxidative stress, fish adapted to either increase or decrease in antioxidants level. This is also true to the report made by Sunaini., et al. (2016) reporting that catalase activity was decreased after exposure to sub - lethal dose of arsenic. Com- 
paring all the results to the control, it is safe to say that there was an increase in catalase activity across all the fish samples assayed; which is in contrast with the research conducted by Sunaini., et al. (2016) who recorded lower catalase activity in muscle of fish after exposure to sub - lethal doses of arsenic. Their findings was largely due to the fact that the fish they used in their researches was from rivers which had a good chance of getting contaminated by arsenic, which explains why they recorded a significant accumulation, and consequently record catalase activity in the control. With this in mind, it vital to know that variation in responses of the antioxidant enzymes to metal exposures, depends upon body tissues, metals and exposure types (lethal or sub - lethal) (Pandey., et al. 2011). Toxicity of compounds to organisms has however been known to be dependent on concentration, sex, developmental stages, and exposure periods (Pandey., et al. 2011).This study suggest that catalase which is antioxidant in function is highly sensitive to metal pollution as its activities change significantly, suggesting it could be helpful in predicting sub - lethal metal toxicity and useful as an early warning tool in biomonitoring studies [6-25].

\section{Conclusions}

The present findings suggest that in the muscle tissue of Clarias gariepinus, arsenic activity is dependent on quantity or concentration introduced, as well as concentration accumulated; as activity increased with increased accumulation. This suggests that even at sub-lethal concentration arsenic can induce oxidative stress resulting in alterations in catalase activity in the muscle of the fishes. On the basis of results obtained in this study and previous studies, it can be concluded that antioxidant enzymes like catalase (CAT) and others are helpful in preventing the harmful effects of heavy metals. Moreover, they are cautionary indicators for severe damage to organisms living in aquatic environment. The consequence of this research work further reveals that catalase (CAT) is a susceptible bio-indicator of an organisms' antioxidant defense system. However, it is still essential to study further antioxidant enzymes in different aquatic animal models for better understanding.

\section{Bibliography}

1. Ahmed AAM., et al. "Evaluation of socioeconomic impact of arsenic contamination in Bangladesh". Journal of Toxicological and Environmental Health Sciences 3.10 (2011): 298-307.

2. Avci A., et al. "Peroxidation in muscle and liver tissues from fish in a contaminated riverdue to a petroleum refinery industry". Ecotoxicology of Environmental Safety 60.1 (2005): 101105.

3. Atli G and Canli M. "Enzymatic responses to metal exposures in a fresh water fish Oreochromisniloticus". Comprehensive Biochemical and Physiological Chemistry 145.2 (2008): 282287.
4. Tyokumbur ET., et al. "Bioaccumulation of arsenic and uranium in two fish species (Clarias lazera and Tilapia zilli) from Alaro stream in Ibadan, Nigeria". Health Sciences Research 1.4 (2014): 68-71.

5. Firat $\mathrm{O}$ and Kargin F. "Effects of zinc and cadmium on erythrocyte antioxidant systems of fresh water fish Oreochromis niloticus". Journal of Biochemical and Molecular Toxicology 24.4 (2010): 223-229.

6. Alinnor IJ and Obiji IA. "Assessment of trace metal composition in fish samples from Nworie River". Pakistan Journal of Nutrition 9.1 (2010): 81-85.

7. Banerjee S., et al. "Seasonal variation in heavy metal contaminations in water and sediments of Jamshedpur stretch of Subarnarekha River, India". Journal of Environmental and Earth Science 75 (2016): 265-266.

8. Britz PJ and Pienaar AG. "Laboratory experiments on the effect of light and cover on the behaviour and growth of African catfish, Clarias gariepinus (Pisces: Clariidae)". Journal of Zoology 227 (1992): 43-62.

9. Bruton MN. "The food and feeding behaviour of Clariasgariepinus (Pisces: Clariidae) in Lake Sibaya, South Africa, with emphasis on its role as a predator of cichlids". Transactions of the Zoological Society of London 35 (1979): 47-114.

10. Chen Y., et al. "The role of nodes in arsenic storage and distribution in rice". Journal of Expositional Botany 66 (2015): 3717 3724 .

11. Das S., et al. "Toxicological effects of arsenic exposure in a freshwater teleost fish, Channapunctatus". African Journal of Biotechnology 47.5 (2012):1-9.

12. Druwe IL and Vaillancourt RR. "Influence of arsenate and arsenite on signal transduction pathways: an update". Archaelogical Toxicology 84.8 (2010): 585-596.

13. Erickson RJ., et al. "The relative importance of waterborne and diet borne arsenic exposure on survival and growth of juvenile rainbow trout". Journal of Aquatic Toxicology 104.1-2 (2011): $108-115$

14. Gaim K., et al. "The effect of arsenic on liver tissueof experimental animals (fishes and mice)-a review article". International Journal of Scientific and Research Publications 5.5 (2015):1-9.

15. Hecht $\mathrm{T}$ and Appelbaum S. "Notes on the growth of Israeli sharptooth catfish (Clarias gariepinus) during the primary nursing phase". Aquaculture 63 (1987): 195-204.

16. Hughes MF., et al. "Arsenic exposure and toxicology: a historical perspective". Toxicological Science 123.2 (2011): 305-332. 
17. Iyer S., et al. "Blood arsenic: pan-India prevalence". Clinical Chimica Act 455 (2016): 99-101.

18. Kamaruzzaman BY., et al. "Concentration of $\mathrm{Zn}, \mathrm{Cu}$ andPb in someSelected Marine Fishes of the Pahang Coastal Waters, Malaysia". American Journal of Applied Sciences 7.3 (2010): 309-314.

19. Kar S., et al. "Health risks for human intake of aquacultural fish: arsenic bioaccumulation and contamination". Journal of Environmental Health Science 46.11 (2011):1266-1273.

20. Tiwari S., et al. "In silico arsenate reductase gene evolution". Online Journal of Bio Information 16 (2015): 303-317.

21. Ventura-Lima J., et al. "Arsenic toxicity inmammals and aquatic animals: a comparative biochemical approach". Ecotoxicology and Environmental Safety 74.3 (2010): 211-218.

22. Volodymyr IL. "Environmentally induced oxidative stress in aquatic animals". Aquatic Toxicology 101.1 (2011): 13-30.

23. Wang P., et al. "A review on completing arsenic biogeochemicalcycle: microbial volatilization of arsines in environment". Journal Environmental Sciences 26.2 (2014): 371-381.

24. Xu H., et al. "Genome-wide identificationof molecular pathways and biomarkers in response to arsenicexposure in zebrafishliver". PLoS One 8.7 (2013): 68-73.

25. Zhang SY., et al. "Bio-methylation and volatilization ofarsenic by the marine microalgae Ostreococcustauri". Chemosphere 93.1 (2013): 47-53.

\section{Volume 2 Issue 10 October 2019}

(C) All rights are reserved by Ujah II and Chikezie NJ. 